\title{
Article \\ Polyphenol-Rich Black Elderberry Extract Stimulates Transintestinal Cholesterol Excretion
}

\author{
Sohyeon Jeon, Minji Kim and Bohkyung Kim *
}

check for updates

Citation: Jeon, S.; Kim, M.; Kim, B. Polyphenol-Rich Black Elderberry Extract Stimulates Transintestinal Cholesterol Excretion. Appl. Sci. 2021, 11, 2790. https://doi.org/10.3390/ app11062790

Academic Editor:

Wojciech Kolanowski

Received: 4 March 2021

Accepted: 18 March 2021

Published: 21 March 2021

Publisher's Note: MDPI stays neutral with regard to jurisdictional claims in published maps and institutional affiliations.

Copyright: (c) 2021 by the authors. Licensee MDPI, Basel, Switzerland. This article is an open access article distributed under the terms and conditions of the Creative Commons Attribution (CC BY) license (https:// creativecommons.org/licenses/by/ $4.0 /)$.

\author{
Department of Food Science and Nutrition, Pusan National University, Busan 46241, Korea; \\ hyeoneee@pusan.ac.kr (S.J.); minjikim17@pusan.ac.kr (M.K.) \\ * Correspondence: bohkyung.kim@pusan.ac.kr; Tel.: +82-51-510-2844
}

\begin{abstract}
Hypercholesterolemia is the primary risk factor for cardiovascular disease (CVD). Recent studies reported that the stimulation of transintestinal cholesterol excretion (TICE), a nonbiliary cholesterol excretion, can be a strategy for preventing CVD. Black elderberry (Sambucus nigra) has been reported to reduce the risk of CVD via its antioxidant, anti-inflammatory, and hypocholesterolemic effects. However, little is known about the role of black elderberry in intestinal cholesterol metabolism despite its well-known effects on cholesterol homeostasis regulation. To investigate the effects of polyphenol-rich black elderberry extract (BEE) on intestinal cholesterol metabolism, we measured the expression of genes involved in cholesterol biosynthesis and flux in Caco-2 cells. BEE significantly decreased the messenger RNA (mRNA) and protein levels of genes for cholesterol absorption, such as Niemann-Pick C1 Like 1 and ATP-binding cassette transporter A1 (ABCA1). In contrast, there was marked induction of low-density lipoprotein receptor, ABCG5/G8, and ABCB1 in BEE-treated Caco-2 cells. Furthermore, BEE decreased the expression of genes for lipogenesis and altered the mRNA levels of sirtuins. All of the genes altered by BEE were in the direction of flux cholesterol from the basolateral to apical side of enterocytes, indicating stimulation of TICE. These results support the hypocholesterolemic effects of BEE for the prevention of CVD.
\end{abstract}

Keywords: black elderberry; hypocholesterolemia; transintestinal cholesterol excretion; Caco-2 cells

\section{Introduction}

Cardiovascular disease (CVD) is one of the largest causes of mortality worldwide. Hypercholesterolemia and hypertriglyceridemia are significant risk factors for CVD [1]. Cholesterol synthesis and absorption are critical factors for plasma cholesterol concentration $[2,3]$. Common medications used to treat or reduce hypercholesterolemia target blocking hepatic cholesterol synthesis or intestinal cholesterol absorption [4]. The liver is known as a primary site for the regulation of cholesterol metabolism. It plays a central role in de novo cholesterol synthesis, assembly, and uptake of cholesterol-containing lipoprotein, with conversion of cholesterol to bile acids for the secretion of biliary cholesterols [3,4]. Therefore, most of the studies about the regulation of cholesterol homeostasis have focused on the liver $[4,5]$. The intestine contributes to cholesterol balance by absorbing dietary and biliary cholesterol, and the role of the intestine in cholesterol net balance regulation has been underestimated [6-11]. Hepatobiliary excretion through high-density lipoprotein (HDL)-driven reverse cholesterol transport has been widely accepted as the only way to remove cholesterol from the body [3,12]. Recent studies have revealed a non-biliary pathway for cholesterol excretion, i.e., the transintestinal cholesterol excretion (TICE) pathway [13-15]. In TICE, cholesterol is directly transported into enterocytes from circulation and subsequently excreted into the intestinal lumen [16-18]. Effective medications for stimulation of hepatobiliary excretion can lower hypercholesterolemia but increase gallstone formation [19]. Therefore, targeting the intestine for non-biliary cholesterol excretion to reduce hypercholesterolemia using dietary components or nutrients offers an attractive strategy for preventing CVD. 
Black elderberry (Sambucus nigra) contains a relatively high amount of polyphenols, especially anthocyanin [20]. It is commonly used in Europe and North America as a folk medicine to support immune function and to treat stomach ache, constipation, and diarrhea [21]. In vitro, animal, and clinical trials reported the health benefits of black elderberries for prevention of chronic disease [22-30]. Black elderberry is widely used in the food and nutraceutical industries as an antioxidant and anti-inflammatory agent $[20,21]$. Polyphenols have been suggested as a bioactive component to reduce CVD risk by attenuating oxidative stress, inflammation, and hypercholesterolemia [31-36]. Black elderberry rich in polyphenols exerted protective effects on hyperlipidemia [22,23]. Black elderberry attenuated inflammation and obesity-related complications in diet-induced obese mice [22] Furthermore, black elderberry improved HDL function and reduced aortic cholesterol in apoE knockout mice [23]. However, little is known about the effects of polyphenol-rich black elderberry (BEE) on intestinal cholesterol metabolism. Polyphenol-abundant natural products, i.e., black chokeberry and blackcurrant, altered the genes involved in intestinal cholesterol metabolism in the direction of stimulating the TICE pathway, with the flux of cholesterol from the basolateral to apical side of enterocytes $[37,38]$. In the present study, we investigated whether BEE could exert hypocholesterolemic effects by regulating genes involved in the intestinal cholesterol flux using Caco-2 cells.

\section{Materials and Methods}

\subsection{Cell Culture and Sample Treatment}

The human colorectal adenocarcinoma Caco-2 cells (ATCC, Manassas, VA, USA) were cultured in Dulbecco's modified Eagle's medium containing $100 \mathrm{U} / \mathrm{mL}$ penicillin, $100 \mu \mathrm{g} / \mathrm{mL}$ streptomycin, $1 \times$ vitamins, $1 \times$ nonessential amino acids, and $10 \%$ fetal bovine serum. The cells were maintained in a humidified incubator at $37{ }^{\circ} \mathrm{C}$ with $5 \% \mathrm{CO}_{2}$. Polyphenol-rich black elderberry extract (BEE) was kindly provided by Artemis International (Fort Wayne, IN, USA). The cells were treated with desired concentrations of BEE for $24 \mathrm{~h}$. Cells without BEE treatment were considered as a control. All reagents, unless stated, were purchased from Hyclone (South Logan, UT, USA).

\subsection{Cytotoxicity of $B E E$}

Cytotoxicity of BEE was examined by Cell Counting Kit-8 (Dojindo Molecular Technologies, Rockville, MD, USA) following the manufacturer's instructions. Increasing concentrations of BEE from 0 to $200 \mu \mathrm{g} / \mathrm{mL}$ were applied to Caco- 2 cells for $24 \mathrm{~h}$. The positive control, sodium dodecyl sulfate $(0.5 \mathrm{mmol} / \mathrm{L})$, confirmed the validity of the assay as showing near-zero cytotoxicity. The cytotoxicity of BEE was indicated as the cell viability $(\%)$ of controls that were not treated with BEE.

\subsection{Quantitative Real-Time PCR}

The gene expression was measured by quantitative real-time PCR analysis as previously described $[37,38]$. Briefly, total RNA was extracted using Trizol reagent (Life Technologies, Carlsbad, CA, USA), and the concentration was determined using Cytation1 (BioTek, Winooski, VT, USA). The RNA samples were reverse-transcribed to complementary DNA (cDNA) by Moloney murine leukemia virus (MMLV) reverse transcriptase (Promega, Madison, WI, USA). The quantitative real-time PCR was analyzed using the SYBR Green procedure and CFX96 real-time PCR (Bio-Rad, Hercules, CA, USA). The threshold cycle (Ct) value was used to calculate the expression of messenger RNA (mRNA) values. The relative expression of the target mRNA was measured by using the $2^{-\Delta \Delta C t}$ method. According to GenBank, the primer sequences were designed by the Beacon Designer (Premier Biosoft, Palo Alto, CA, USA). The primer sequences are provided in Table 1. 
Table 1. The primer sequences for qRT-PCR analysis.

\begin{tabular}{|c|c|c|}
\hline Genes & Forward & Reverse \\
\hline HMGR & 5'-CCCAGTTGTGCGTCTTCCA-3' & 5'-TTCGAGCCAGGCTTTCACTT-3' \\
\hline SREBP2 & 5'-TCCGCCTGTTCCGATGTAC-3' & 5'-TGCACATTCAGCCAGGTTCA-3' \\
\hline NPC1L1 & 5'-CACTGGATCACTCGAGGTGTTG-3' & 5'-CCAGTCCCACGCTGATGTG-3' \\
\hline$S R-B 1$ & 5'-AGAATAAGCCCATGACCCTGAA-3' & $5^{\prime}-$ CGCCGAGGGTGGTGAA-3' \\
\hline$A B C A 1$ & 5'-TTTCTCAGACAACACTTGACCAAGTA-3' & 5'-GGTTTTTGTGTAATGAGAGGTCTTTTAA-3' \\
\hline MTTP & 5'-TCCCCGTTCGGCATCTAC-3' & 5'-CTTAGAATGCCAGAACCCGAGTA-3' \\
\hline ACAT2 & 5'-TGGGCCACCCTCTTGGA-3' & 5'-CCAGTGTGTGTAACAGGGTCACA-3' \\
\hline$L D L R$ & 5-ACTGGGTTGACTCCAAACTTCAC-3' & 5-GGTTGCCCCCGTTGACA-3' \\
\hline PCSK9 & 5'-TTCCTGGTGAAGATGAGT-3' & 5'-TTCCTGGTGAAGATGAGT-3' \\
\hline ABCG5 & 5'-GCGTAGGTCTCCTTTACCAGTTTG-3' & 5'-GGAAACAGATTCACAGCGTTCA-3' \\
\hline ABCG8 & 5'-GCCGCCCTCTTGTTCATG-3' & 5'-TAACATTTGGAGATGACATCCAGAA-3' \\
\hline$A B C B 1$ & 5'-CTATAATGCGACAGGAGA-3' & 5'-TTAATCTTGGAGACATCATC-3' \\
\hline FAS & 5'-CGCTCGGCATGGCTATCT-3' & 5'-CTCGTTGAAGAACGCATCCA-3' \\
\hline$S C D-1$ & 5'-CCGACGTGGCTTTTTCTTCT-3' & 5'-TGGGTGTTTGCGCACAAG-3' \\
\hline SREBP1c & 5'-TCAGCGAGGCGGCTTTGGAGCAG-3' & 5'-CATGTCTTCGATGTCGGTCAG-3' \\
\hline CPT1 & 5'-TTATCGCCAAGGATGGCTCTA-3' & 5'-CСАСАССАТСАССССАAGA-3' \\
\hline$A C O X$ & 5'-CTTGCTTCACCAGGCAACTG-3' & 5'-TTCCAGGCGGGCATGA-3' \\
\hline SIRT1 & 5'-TAGTTCTTGTGGCAGTAA-3' & 5'-CATCAGGCTCATCTTCTA-3' \\
\hline SIRT2 & 5'-AACCATCTGTCACTACTT-3' & 5'-TATCTATGTTCTGCGTGTA-3' \\
\hline SIRT3 & 5'-GCTCCCAGTTTCTTCTTT-3' & 5'-ССАСТТССААСААСАСТТ-3' \\
\hline SIRT4 & 5'-СТТСАТСАСССТТТССАА-3' & 5'-ACCTGTAGTCTGGTATCC-3' \\
\hline SIRT5 & 5'-AAGCACATAGTCATCATCT-3' & 5'-TTCТССАATAАССТCCAG-3' \\
\hline SIRT6 & 5'-AGGGACAAACTGGCAGAG-3' & 5'-TGTGTCTCGGACGTACTG-3' \\
\hline SIRT7 & 5'-AATACTTGGTCGTCTACAC-3' & 5'-TGTCCACACTCCATTAGG-3' \\
\hline GAPDH & 5'-GGTGGTCTCCTCTGACTTCAACA-3' & 5'-GTTGCTGTAGCCAAATTCGTTGT-3' \\
\hline
\end{tabular}

\subsection{Western Blot}

The protein levels in BEE-treated Caco-2 cells were measured by Western blot analysis as previously described [37]. Chemidoc XRS+ (Bio-Rad) and Image Lab software (Bio-Rad) were used for the analysis. The antibodies for ATP-binding cassette transporter A1 (ABCA1), ABCB1, ABCG5, 3-hydroxy-3-methylglutaryl coenzyme A reductase (HMGR), low-density lipoprotein (LDL) receptor (LDLR), Niemann-Pick C1 Like 1 (NPC1L1), proprotein convertase subtilisin/kexin type 9 (PCSK9), scavenger receptor class B type 1 (SR-B1), and sterol regulatory element-binding protein 2 (SREBP-2) were purchased from Abcam (Cambridge, MA, USA). $\beta$-Actin (Sigma, St. Louis, MO, USA) was used as a loading control.

\subsection{Statistical Analysis}

One-way analysis of variance (ANOVA) and Newman-Keuls post hoc analysis were performed to detect significance.

\section{Results}

\subsection{Cytotoxicity of BEE in Caco-2 Cells}

The cytotoxicity of BEE was assessed by measuring the cell viability of Caco-2 cells treated with increasing concentrations of BEE for $24 \mathrm{~h}$. There was no significant reduction in the viability of the cells treated with up to $50 \mu \mathrm{g} / \mathrm{mL}$ BEE. The cells treated with $100 \mu \mathrm{g} / \mathrm{mL}$ 
BEE exerted a significant reduction in cell viability. However, the cell viability was above $90 \%$ until $100 \mu \mathrm{g} / \mathrm{mL}$ BEE. Therefore, 50 or $100 \mu \mathrm{g} / \mathrm{mL}$ BEE was used in the subsequent experiments (Figure 1).

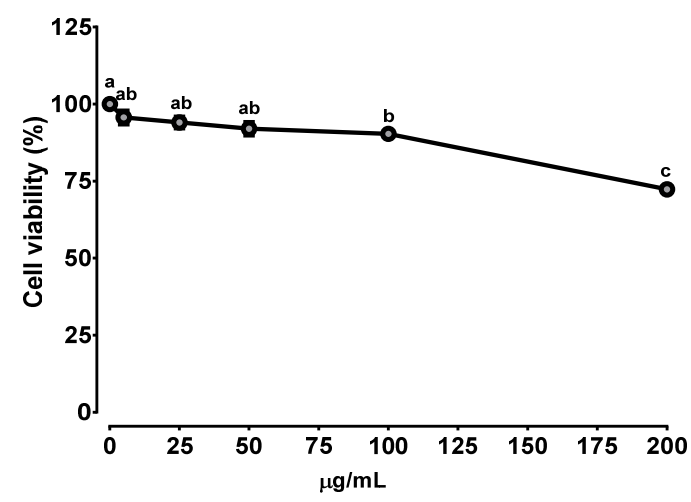

Figure 1. Cytotoxicity of polyphenol-rich black elderberry extract (BEE)-treated Caco-2 cells. Cells were treated with increasing concentrations $(0-200 \mu \mathrm{g} / \mathrm{mL})$ of BEE for $24 \mathrm{~h}$. The viability (\%) is presented relative to controls without BEE treatment. Data with different letters are significantly different $(p<0.05)$. Values are means \pm SEM; $n=6$.

\subsection{Effects of BEE on the Genes Involved in Cholesterol Synthesis and Absorption}

To investigate the effects of BEE on intestinal cholesterol metabolism, we first measured the mRNA expressions of genes involved in the synthesis and absorption of cholesterol in BEE-treated Caco-2 cells. BEE significantly and dose-dependently decreased the expression of HMGR and SREBP2, i.e., the rate-controlling enzyme in cholesterol biosynthesis and its transcription factor, respectively (Figure 2). The expression of genes for cholesterol absorption, such as NPC1L1 and SR-B1, was dose-dependently and significantly decreased by BEE. Furthermore, the mRNA abundance of $A B C A 1$, the basolateral transporter of cholesterol, was significantly decreased in BEE-treated cells. For the genes involved in chylomicron assembly, the mRNA abundance of microsomal triglyceride transfer protein (MTTP) and acetyl-CoA Acetyltransferase 2 (ACAT2) was significantly decreased in BEEtreated Caco-2 cells (Figure 2). Consistent with the mRNA results, the protein levels of HMGR and SREBP2 were decreased by BEE treatment. Furthermore, the protein levels of transporters for cholesterol absorption, i.e., NPC1L1, SR-B1, and ABCA1, were noticeably lowered in BEE-treated Caco-2 cells (Figure 3).

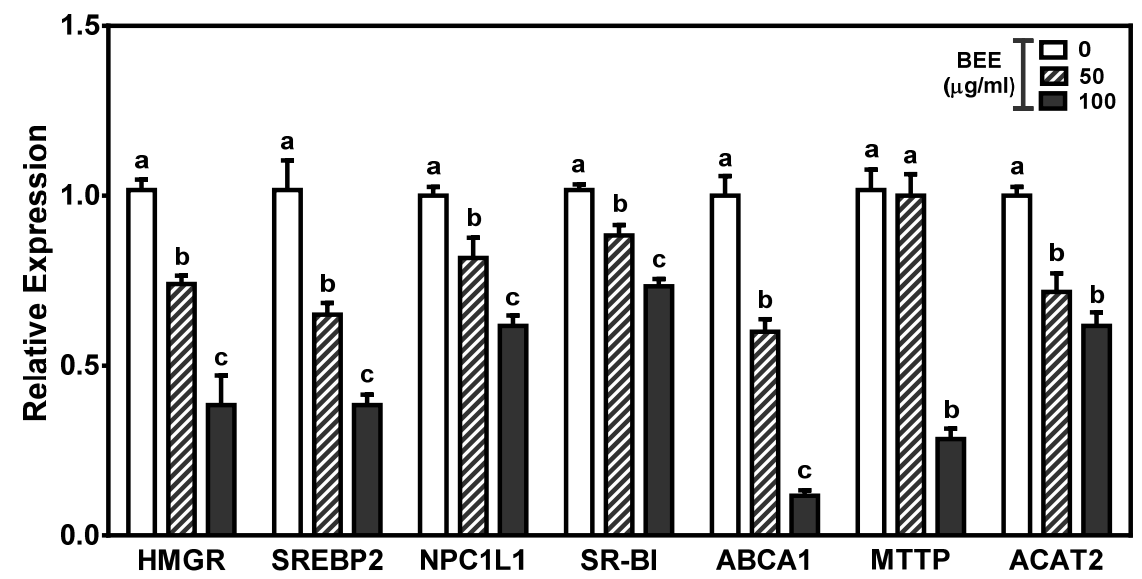

Figure 2. The effects of BEE on the genes involved in the synthesis and absorption of cholesterol in Caco- 2 cells. Cells were treated with 50 or $100 \mu \mathrm{g} / \mathrm{mL}$ BEE for $24 \mathrm{~h}$. The messenger RNA (mRNA) abundance was measured by qRT-PCR analysis. Data are expressed as relative expressions to control. Bars with different letters are significantly different $(p<0.05)$. Values are means \pm SEM; $n=6$. 


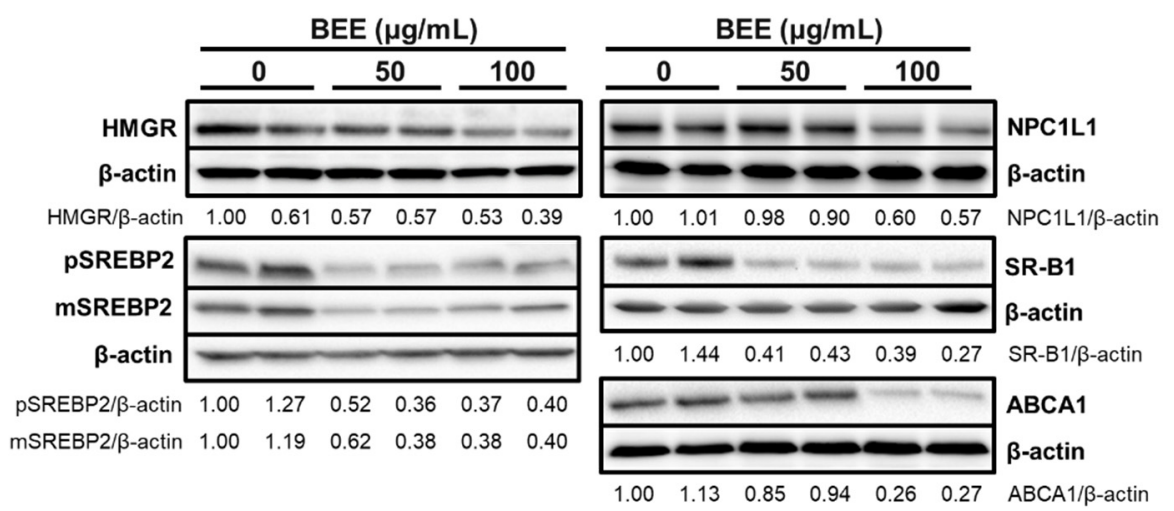

Figure 3. The effects of BEE on the proteins involved in cholesterol biosynthesis and absorption in Caco- 2 cells. The cells were treated with 50 or $100 \mu \mathrm{g} / \mathrm{mL}$ BEE for $24 \mathrm{~h}$. The Western blot was conducted twice, and the representative image is shown. $\beta$-Actin was used as a loading control. Densitometry analysis was performed to measure the relative intensity, and the values are shown under each protein band.

\subsection{Alteration of the Genes Involved in TICE by BEE}

As BEE repressed the genes for intestinal cholesterol biosynthesis and absorption, we further examined whether BEE could alter the genes involved in the TICE pathway. The expression of $L D L R$, the receptor that mediates the endocytosis of LDL-derived cholesterol, was significantly and dose-dependently increased in BEE-treated Caco-2 cells. The mRNA abundance of PCSK9, the protease that promotes LDLR degradation, was not altered by BEE treatment. Furthermore, BEE significantly and dose-dependently increased the mRNA abundance of $A B C A G 5$ and $A B C G 8$, the apical heterodimeric transporters that flux cholesterol back to the intestine. A significant increase in the expression of $A B C B 1$, the multidrug transporter present in the apical membrane of enterocytes, was observed by BEE treatment (Figure 4a). The protein levels of LDLR, ABCG5, and ABCB1 were markedly increased by BEE treatment, confirming the effects of BEE on the stimulation of TICE in Caco- 2 cells (Figure $4 b$ ).

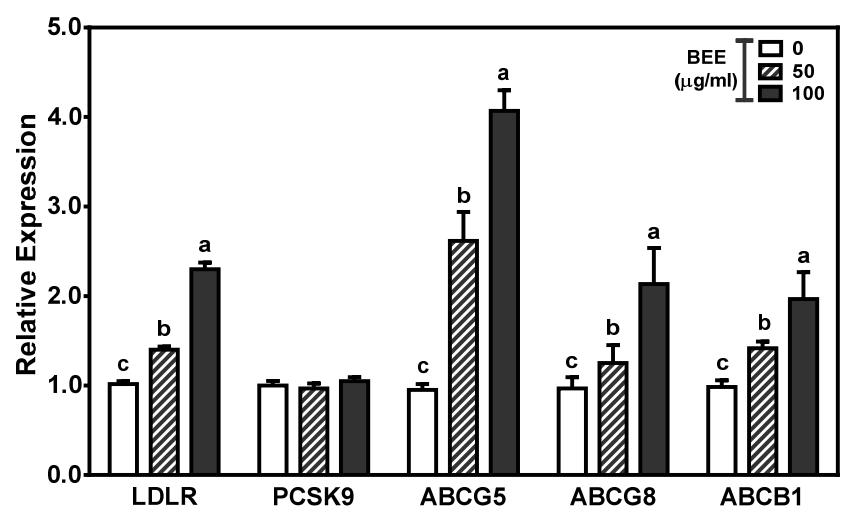

(a)

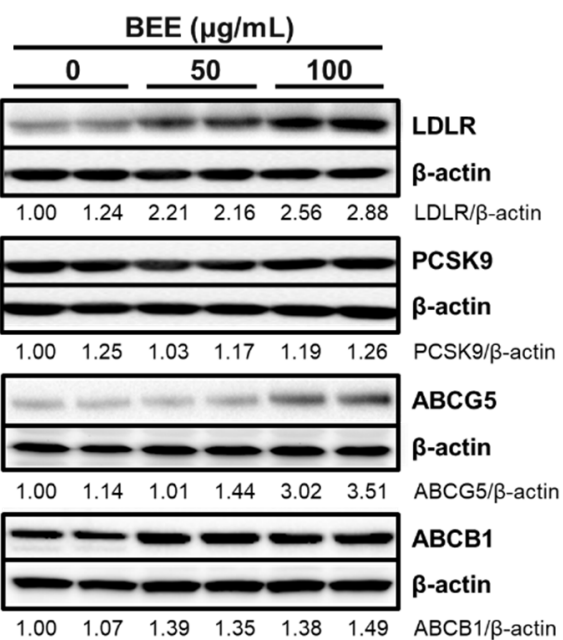

(b)

Figure 4. The effect of BEE on the genes involved in the transintestinal cholesterol excretion (TICE) pathway in Caco-2 cells. The cells were treated with 50 or $100 \mu \mathrm{g} / \mathrm{mL}$ BEE for $24 \mathrm{~h}$. (a) The mRNA abundance was measured by qRT-PCR analysis. Data are expressed as relative expressions to control. Bars with different letters are significantly different $(p<0.05)$. Values are means $\pm \mathrm{SEM} ; n=6$. (b) The Western blot was conducted twice, and the representative image is shown. $\beta$-Actin was used as a loading control. The densitometry analysis was performed to measure the relative intensity, and the values are shown under each protein band. 


\subsection{Effects of BEE on the Genes Involved in Fatty-Acid Metabolism}

To investigate the effects of BEE on fatty-acid metabolism, we first measured the genes involved in de novo lipogenesis. The mRNA abundance of fatty acid synthase (FAS) and stearoyl-CoA desaturase-1 (SCD-1) was significantly decreased by $100 \mu \mathrm{g} / \mathrm{mL} \mathrm{BEE}$ with a concomitant decrease in SREBP1c, the transcription factor for lipogenesis. Next, the expression of genes for fatty-acid oxidation was measured. The mRNA expression of acyl-coenzyme A oxidase ( $A C O X)$, the gene for peroxisomal fatty acid oxidation, was significantly and dose-dependently decreased by BEE treatment (Figure 5).

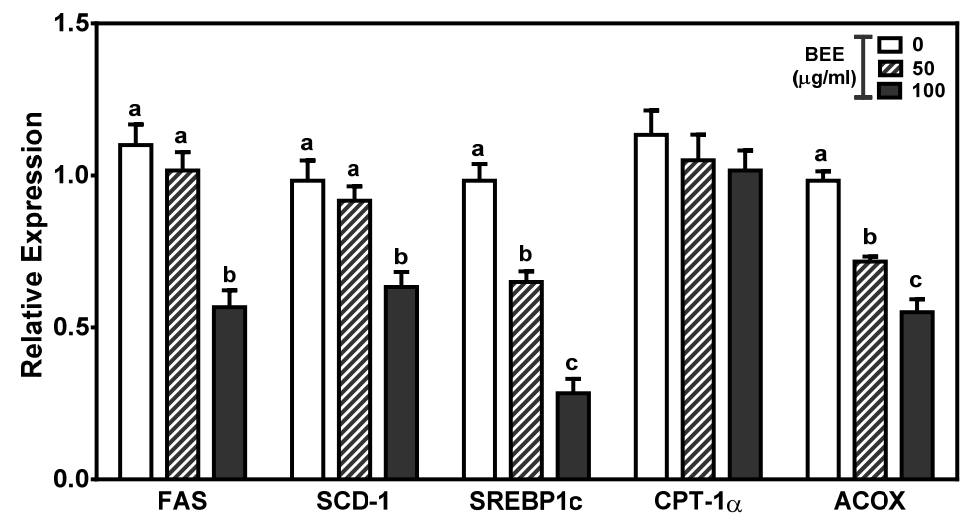

Figure 5. The effect of BEE on fatty-acid metabolism in Caco-2 cells. Cells were treated with 50 or $100 \mathrm{\mu g} / \mathrm{mL}$ BEE for $24 \mathrm{~h}$. The expression of genes involved in fatty-acid metabolism was measured by qRT-PCR. Data are expressed as relative expressions of control. Bars with different letters are significantly different $(p<0.05)$. Values are means $\pm \mathrm{SEM} ; n=6$.

\subsection{Effects of BEE on the Regulation of SIRT}

The potential effects of BEE on the regulation of sirtuins (SIRTs) were investigated by measuring the expression of seven different SIRT isoforms in $100 \mu \mathrm{g} / \mathrm{mL}$ BEE-treated Caco-2 cells. Significant increases in the gene expression of SIRT1, SIRT3, and SIRT6 were observed in BEE-treated cells. In contrast, the mRNA abundance of SIRT2 was significantly reduced by BEE. There was no significant alteration of SIRT4, SIRT5, and SIRT7 by BEE treatment (Figure 6).

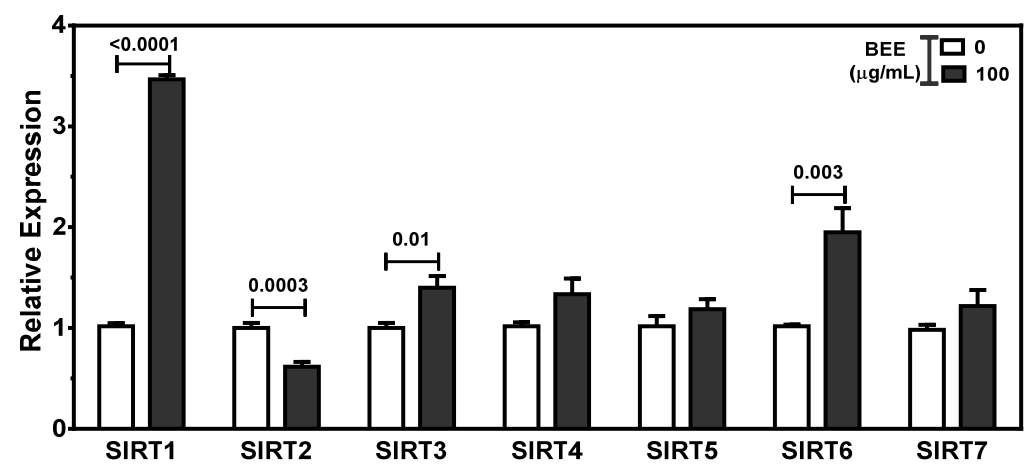

Figure 6. The effect of BEE on the expression of sirtuins (SIRTs) in Caco-2 cells. Cells were treated with $100 \mu \mathrm{g} / \mathrm{mL}$ BEE for $24 \mathrm{~h}$. The expression of SIRT isoforms was measured by qRT-PCR. Data are expressed as relative expressions of control. $p$ values of significant differences are shown as above bars. Values are means $\pm \mathrm{SEM} ; n=6$.

\section{Discussion}

Hypercholesterolemia is one of the primary risk factors for the prevalence of CVD [39]. Cholesterol homeostasis is tightly regulated by the interplay of the liver and in the intestine $[4,6]$. Therefore, the hypolipidemic effects of drugs or dietary components target either 
blocking cholesterol synthesis in the liver or inhibiting intestinal cholesterol absorption. Classically, hepatobiliary cholesterol excretion mediated by reverse cholesterol transport has been considered the only way to remove cholesterol from the body [12]. Recently, several publications reported the direct contribution of TICE to fecal neutral sterol in mice models and humans [40-46]. In this non-biliary cholesterol excretion pathway, the plasma lipoprotein-derived cholesterol is transported from the basolateral to the apical side of enterocytes for direct excretion [47]. The underlying mechanisms regulating TICE are still unclear, but the significant contribution of TICE to cholesterol excretion gives an attractive strategy for preventing CVD.

The protective effects of polyphenols against hypercholesterolemia are well known. Black elderberry (Sambucus nigra) is well known for its cardioprotective effects by exerting hypolipidemia and improving lipid profiles, oxidative stress, and inflammation [22-24]. Black elderberry alleviated oxidative stress, insulin resistance, and inflammation in 3T3-L1 cells [29]. In particular, black elderberry improved cholesterol profiles and HDL functions in animal studies [23]. High contents of polyphenol in the black elderberry are claimed to be responsible for these effects. Natural products high in polyphenols altered the genes involved in the TICE pathway $[37,38]$.

In the present study, to gain insight into the mechanism of BEE on intestinal cholesterol metabolism, we investigated if BEE could alter the genes involved in the biosynthesis and flux of cholesterol in Caco-2 cells. The genes for intestinal cholesterol metabolism were markedly induced by BEE treatment. HMGR is a rate-limiting enzyme for cholesterol biosynthesis, and its inhibitor, statin, is widely prescribed to lower plasma cholesterol [48,49]. SREBP2, a master of regulation for cholesterol metabolism, is primarily responsible for the transcription of HMRG and LDLR [50]. There was a significant reduction in both mRNA and protein levels of HMGR and SREBP2 by BEE. Intestinal free cholesterol absorption is mediated by several transporters and enzymes such as NPC1L1, SR-B1, ABCA1, ACAT2, and MTTP $[10,51]$. We observed that BEE significantly decreased mRNA and protein levels of NPCIL1 in Caco-2 cells. NPC1L1, a sterol transporter, present in the apical membrane of enterocytes, mediates cholesterol absorption in the intestine [52,53]. Ezetimibe, an NPC1L1 inhibitor, has been used for lowering cholesterol by inhibiting cholesterol absorption $[54,55]$. Therefore, the reduction in NPC1L1 by BEE treatment also supports the hypocholesterolemic effects of black elderberry. ABCA1 is responsible for basolateral cholesterol efflux [56]. We observed significant decreases in both mRNA and protein levels of ABCA1 in Caco-2 cells. Cholesterol absorption in the intestine is closely involved with chylomicron assembly and secretion. ACAT2 esterifies cholesterol for absorption [57], and MTTP assembles and secretes chylomicron from enterocytes to the basolateral lumen, facilitating intestinal cholesterol absorption [10]. The expression of ACAT2 and MTTP was significantly decreased in BEE-treated Caco-2 cells. Consistent with our results, apple polyphenols decreased lipoprotein secretion, contributing to its hypolipidemic effects in Caco-2/TC7 enterocytes [58]. All of the genes involved in the flux of cholesterol from the apical to basolateral side of enterocytes were decreased by BEE treatment.

Intestine-specific stimulation of TICE can be an alternative pathway for cholesterol excretion. The underlying mechanisms of TICE are still unknown, but intestinal SR-B1 and HDL are not involved in the process of TICE [41]. In contrast, LDL-derived cholesterol and LDLR have been reported to be involved in the alteration of TICE. Notably, we observed significant increases in both mRNA and protein levels of LDLR in BEE-treated Caco-2 cells. To investigate the underlying mechanisms of LDLR alteration by BEE, we measured whether BEE could induce PCSK9. PCSK9, responsible for LDLR protein degradation, was not altered by BEE. The heterodimer ABCG5/G8 is a well-known transporter for cholesterol flux to the intestinal lumen. Furthermore, LDL-derived cholesterol taken up by LDLR can be effluxed to the intestinal lumen via ABCG5/G8, stimulating TICE. In the process of TICE, the cholesterols can be transported from the basolateral to the apical side of the enterocyte for subsequent excretion from the body. BEE increased both mRNA and protein levels of ABCG5, which may decrease intestinal cholesterol absorption. ABCG5/G8 
transporters mediate the flux of free cholesterol to the intestinal lumen [59]. ABCB1, the apical transporter, acts as a cholesterol floppase and plays an essential role in TICE [60]. BEE markedly increased the mRNA and protein levels of ABCB1. These results indicate that BEE may stimulate the transporters involved in cholesterol flux from the basolateral to apical side of enterocytes.

The availability of triglycerides regulates the assembly of lipoproteins $[9,10]$. Therefore, we measured the genes involved in fatty-acid metabolism in BEE-treated Caco- 2 cells. BEE decreased the expression of lipogenic transcription factor SREBP1c and its downstream genes such as FAS and SCD-1. According to our results, there was a marked alteration of genes involved in intestinal cholesterol and lipid metabolism. Mammalian sirtuins (SIRTs), nicotinamide adenine dinucleotide-dependent deacetylases, are known as epigenetic and physiological regulators of biological metabolism [61,62]. Mounting evidence supports that SIRTs can regulate cholesterol and lipid metabolism $[63,64]$. Resveratrol, a well-known polyphenol present in wine, is known to modulate SIRT $[65,66]$. Therefore, we investigated whether BEE could alter SIRT expression. We observed an induction of SIRT1, SIRT3, and SIRT6 and a reduction in SIRT2 expression by BEE in Caco-2 cells. Further study is warranted to understand the mechanisms of SIRT alteration by BEE.

All of the gene changes, which occurred in a direction to flux cholesterol from the basolateral to the apical side of the enterocyte, by BEE indicate that black elderberry may lower plasma cholesterol by increasing the uptake of LDLR-mediated cholesterol circulation in the enterocyte. Furthermore, BEE altered the expression of SIRTs. These results indicate that black elderberry might have hypocholesterolemic effects via alteration of the TICE pathway.

\section{Conclusions}

In conclusion, the expression of genes involved in intestinal cholesterol biosynthesis and absorption, chylomicron assembly, and TICE was altered in BEE-treated Caco-2 cells. These results indicate that the stimulation of the intestine-specific TICE pathway by BEE can explain the hypocholesterolemic effects of BEE. Further study is warranted to evaluate which components of BEE are responsible for the effects of BEE on TICE stimulation. The present study supports the beneficial effects of black elderberry for the prevention of hypercholesterolemia.

Author Contributions: Conceptualization, B.K.; methodology, S.J., M.K. and B.K.; investigation, S.J., M.K. and B.K; data curation, S.J., M.K. and B.K.; writing—original draft preparation, S.J. and B.K.; writing - review and editing, B.K.; funding acquisition, B.K. All authors read and agreed to the published version of the manuscript.

Funding: This work was supported by a Pusan National University Research Grant, 2018.

Institutional Review Board Statement: Not applicable.

Informed Consent Statement: Not applicable.

Data Availability Statement: The data presented in this study are available in the article.

Conflicts of Interest: The authors declare no conflict of interest.

\section{References}

1. Virani, S.S.; Alonso, A.; Aparicio, H.J.; Benjamin, E.J.; Bittencourt, M.S.; Callaway, C.W.; Carson, A.P.; Chamberlain, A.M.; Cheng, S.; Delling, F.N.; et al. Heart Disease and Stroke Statistics-2021 Update: A Report From the American Heart Association. Circulation 2021, 143, e254-e743. [CrossRef]

2. Kapourchali, F.R.; Surendiran, G.; Goulet, A.; Moghadasian, M.H. The Role of Dietary Cholesterol in Lipoprotein Metabolism and Related Metabolic Abnormalities: A Mini-review. Crit. Rev. Food Sci. Nutr. 2016, 56, 2408-2415. [CrossRef]

3. Millar, J.S.; Cuchel, M. Cholesterol metabolism in humans: A review of methods and comparison of results. Curr. Opin. Lipidol. 2018, 29, 1-9. [CrossRef]

4. Luo, J.; Yang, H.; Song, B.L. Mechanisms and regulation of cholesterol homeostasis. Nat. Rev. Mol. Cell Biol. 2020, $21,225-245$. [CrossRef] [PubMed] 
5. Morgan, A.E.; Mooney, K.M.; Wilkinson, S.J.; Pickles, N.A.; Mc Auley, M.T. Cholesterol metabolism: A review of how ageing disrupts the biological mechanisms responsible for its regulation. Ageing Res. Rev. 2016, 27, 108-124. [CrossRef]

6. Jakulj, L.; Besseling, J.; Stroes, E.S.G.; Groen, A.K. Intestinal cholesterol secretion: Future clinical implications. Neth. J. Med. 2013, 71, 459-465. [PubMed]

7. von Bergmann, K.; Sudhop, T.; Lutjohann, D. Cholesterol and plant sterol absorption: Recent insights. Am. J. Cardiol. 2005, 96, 10d-14d. [CrossRef] [PubMed]

8. Wang, D.Q. Regulation of intestinal cholesterol absorption. Annu. Rev. Physiol. 2007, 69, 221-248. [CrossRef]

9. Black, D.D. Development and physiological regulation of intestinal lipid absorption. I. Development of intestinal lipid absorption: Cellular events in chylomicron assembly and secretion. Am. J. Physiol. Gastrointest. Liver Physiol. 2007, 293, G519-G524. [CrossRef]

10. Mansbach, C.M., 2nd; Gorelick, F. Development and physiological regulation of intestinal lipid absorption. II. Dietary lipid absorption, complex lipid synthesis, and the intracellular packaging and secretion of chylomicrons. Am. J. Physiol. Gastrointest. Liver Physiol. 2007, 293, G645-G650. [CrossRef]

11. Lammert, F.; Wang, D.Q. New insights into the genetic regulation of intestinal cholesterol absorption. Gastroenterology 2005, 129, 718-734. [CrossRef]

12. Groen, A.K.; Bloks, V.W.; Verkade, H.; Kuipers, F. Cross-talk between liver and intestine in control of cholesterol and energy homeostasis. Mol. Asp. Med. 2014, 37,77-88. [CrossRef] [PubMed]

13. van der Velde, A.E.; Brufau, G.; Groen, A.K. Transintestinal cholesterol efflux. Curr. Opin. Lipidol. 2010, $21,167-171$. [CrossRef] [PubMed]

14. Tietge, U.J.; Groen, A.K. Role the TICE? Advancing the concept of transintestinal cholesterol excretion. Arterioscler. Thromb. Vasc. Biol. 2013, 33, 1452-1453. [CrossRef]

15. van der Velde, A.E.; Vrins, C.L.; van den Oever, K.; Seemann, I.; Oude Elferink, R.P.; van Eck, M.; Kuipers, F.; Groen, A.K. Regulation of direct transintestinal cholesterol excretion in mice. Am. J. Physiol. Gastrointest. Liver Physiol. 2008, 295, G203-G208. [CrossRef]

16. Vrins, C.L. From blood to gut: Direct secretion of cholesterol via transintestinal cholesterol efflux. World J. Gastroenterol. 2010, 16, 5953-5957. [CrossRef] [PubMed]

17. Wegner, C.J.; Kim, B.; Lee, J. Trust your gut: Galvanizing nutritional interest in intestinal cholesterol metabolism for protection against cardiovascular diseases. Nutrients 2013, 5, 208-222. [CrossRef]

18. Wang, D.Q.H.; Portincasa, P.; Tso, P. Transintestinal Cholesterol Excretion: A Secondary, Nonbiliary Pathway Contributing to Reverse Cholesterol Transport. Hepatology 2017, 66, 1337-1340. [CrossRef] [PubMed]

19. Di Ciaula, A.; Wang, D.Q.; Garruti, G.; Wang, H.H.; Grattagliano, I.; de Bari, O.; Portincasa, P. Therapeutic reflections in cholesterol homeostasis and gallstone disease: A review. Curr. Med. Chem. 2014, 21, 1435-1447. [CrossRef] [PubMed]

20. Dominguez, R.; Zhang, L.L.; Rocchetti, G.; Lucini, L.; Pateiro, M.; Munekata, P.E.S.; Lorenzo, J.M. Elderberry (Sambucus nigra L.) as potential source of antioxidants. Characterization, optimization of extraction parameters and bioactive properties. Food Chem. 2020, 330, 127266. [CrossRef]

21. Mlynarczyk, K.; Walkowiak-Tomczak, D.; Lysiak, G.P. Bioactive properties of Sambucus nigra L. as a functional ingredient for food and pharmaceutical industry. J. Funct. Foods 2018, 40, 377-390. [CrossRef]

22. Farrell, N.J.; Norris, G.H.; Ryan, J.; Porter, C.M.; Jiang, C.; Blesso, C.N. Black elderberry extract attenuates inflammation and metabolic dysfunction in diet-induced obese mice. Brit. J. Nutr. 2015, 114, 1123-1131. [CrossRef]

23. Farrell, N.; Norris, G.; Lee, S.G.; Chun, O.K.; Blesso, C.N. Anthocyanin-rich black elderberry extract improves markers of HDL function and reduces aortic cholesterol in hyperlipidemic mice. Food Funct. 2015, 6, 1278-1287. [CrossRef]

24. Millar, C.L.; Norris, G.H.; Jiang, C.; Kry, J.; Vitols, A.; Garcia, C.; Park, Y.K.; Lee, J.Y.; Blesso, C.N. Long-Term Supplementation of Black Elderberries Promotes Hyperlipidemia, but Reduces Liver Inflammation and Improves HDL Function and Atherosclerotic Plaque Stability in Apolipoprotein E-Knockout Mice. Mol. Nutr. Food Res. 2018, 62, e1800404. [CrossRef] [PubMed]

25. Hawkins, J.; Baker, C.; Cherry, L.; Dunne, E. Black elderberry (Sambucus nigra) supplementation effectively treats upper respiratory symptoms: A meta-analysis of randomized, controlled clinical trials. Complement. Ther. Med. 2019, 42, 361-365. [CrossRef]

26. David, L.; Moldovan, B.; Vulcu, A.; Olenic, L.; Perde-Schrepler, M.; Fischer-Fodor, E.; Florea, A.; Crisan, M.; Chiorean, I.; Clichici, S.; et al. Green synthesis, characterization and anti-inflammatory activity of silver nanoparticles using European black elderberry fruits extract. Colloids Surf. B 2014, 122, 767-777. [CrossRef]

27. Barak, V.; Halperin, T.; Kalickman, I. The effect of Sambucol, a black elderberry-based, natural product, on the production of human cytokines: I. Inflammatory cytokines. Eur. Cytokine Netw. 2001, 12, 290-296. [PubMed]

28. Strugala, P.; Loi, S.; Bazanow, B.; Kuropka, P.; Kucharska, A.Z.; Wloch, A.; Gabrielska, J. A Comprehensive Study on the Biological Activity of Elderberry Extract and Cyanidin 3-O-Glucoside and Their Interactions with Membranes and Human Serum Albumin. Molecules 2018, 23, 2566. [CrossRef] [PubMed]

29. Zielinska-Wasielica, J.; Olejnik, A.; Kowalska, K.; Olkowicz, M.; Dembczynski, R. Elderberry (Sambucus nigra L.) Fruit Extract Alleviates Oxidative Stress, Insulin Resistance, and Inflammation in Hypertrophied 3T3-L1 Adipocytes and Activated RAW 264.7 Macrophages. Foods 2019, 8, 326. [CrossRef] [PubMed]

30. Waldbauer, K.; Seiringer, G.; Sykora, C.; Dirsch, V.M.; Zehl, M.; Kopp, B. Evaluation of Apricot, Bilberry, and Elderberry Pomace Constituents and Their Potential To Enhance the Endothelial Nitric Oxide Synthase (eNOS) Activity. ACS Omega 2018, 3, 10545-10553. [CrossRef] [PubMed] 
31. Xu, Z.; Xie, J.; Zhang, H.; Pang, J.; Li, Q.; Wang, X.; Xu, H.; Sun, X.; Zhao, H.; Yang, Y.; et al. Anthocyanin supplementation at different doses improves cholesterol efflux capacity in subjects with dyslipidemia-a randomized controlled trial. Eur. J. Clin. Nutr. 2021, 75, 345-354. [CrossRef]

32. Zhu, Y.; Huang, X.; Zhang, Y.; Wang, Y.; Liu, Y.; Sun, R.; Xia, M. Anthocyanin supplementation improves HDL-associated paraoxonase 1 activity and enhances cholesterol efflux capacity in subjects with hypercholesterolemia. J. Clin. Endocrinol. Metab. 2014, 99, 561-569. [CrossRef] [PubMed]

33. Serraino, I.; Dugo, L.; Dugo, P.; Mondello, L.; Mazzon, E.; Dugo, G.; Caputi, A.P.; Cuzzocrea, S. Protective effects of cyanidin-3O-glucoside from blackberry extract against peroxynitrite-induced endothelial dysfunction and vascular failure. Life Sci. 2003, 73, 1097-1114. [CrossRef]

34. Zafra-Stone, S.; Yasmin, T.; Bagchi, M.; Chatterjee, A.; Vinson, J.A.; Bagchi, D. Berry anthocyanins as novel antioxidants in human health and disease prevention. Mol. Nutr. Food Res. 2007, 51, 675-683. [CrossRef] [PubMed]

35. Mendonca, R.D.; Carvalho, N.C.; Martin-Moreno, J.M.; Pimenta, A.M.; Lopes, A.C.S.; Gea, A.; Martinez-Gonzalez, M.A.; Bes-Rastrollo, M. Total polyphenol intake, polyphenol subtypes and incidence of cardiovascular disease: The SUN cohort study. Nutr. Metab. Cardiovas 2019, 29, 69-78. [CrossRef]

36. Rienks, J.; Barbaresko, J.; Nothlings, U. Review Association of Polyphenol Biomarkers with Cardiovascular Disease and Mortality Risk: A Systematic Review and Meta-Analysis of Observational Studies. Nutrients 2017, 9, 415. [CrossRef] [PubMed]

37. Kim, B.; Park, Y.; Wegner, C.J.; Bolling, B.W.; Lee, J.Y. Polyphenol-rich black chokeberry (Aronia melanocarpa) extract regulates the expression of genes critical for intestinal cholesterol flux in Caco-2 cells. J. Nutr. Biochem. 2013, 24, 1564-1570. [CrossRef] [PubMed]

38. Kim, B.; Bae, M.; Park, Y.K.; Ma, H.; Yuan, T.; Seeram, N.P.; Lee, J.Y. Blackcurrant anthocyanins stimulated cholesterol transport via post-transcriptional induction of LDL receptor in Caco-2 cells. Eur. J. Nutr. 2018, 57, 405-415. [CrossRef]

39. Nelson, R.H. Hyperlipidemia as a Risk Factor for Cardiovascular Disease. Prim. Care 2013, 40, 195-211. [CrossRef]

40. de Boer, J.F.; Schonewille, M.; Boesjes, M.; Wolters, H.; Bloks, V.W.; Bos, T.; van Dijk, T.H.; Jurdzinski, A.; Boverhof, R.; Wolters, J.C.; et al. Intestinal Farnesoid X Receptor Controls Transintestinal Cholesterol Excretion in Mice. Gastroenterology 2017, 152, 1126-1138.e6. [CrossRef]

41. Bura, K.S.; Lord, C.; Marshall, S.; McDaniel, A.; Thomas, G.; Warrier, M.; Zhang, J.; Davis, M.A.; Sawyer, J.K.; Shah, R.; et al. Intestinal SR-BI does not impact cholesterol absorption or transintestinal cholesterol efflux in mice. J. Lipid Res. 2013, 54, 1567-1577. [CrossRef]

42. Farahnak, Z.; Chapados, N.; Lavoie, J.M. Exercise training increased gene expression of LDL-R and PCSK9 in intestine: Link to transintestinal cholesterol excretion. Gen. Physiol. Biophys. 2018, 37, 309-317. [CrossRef] [PubMed]

43. Jakulj, L.; van Dijk, T.H.; de Boer, J.F.; Kootte, R.S.; Schonewille, M.; Paalvast, Y.; Boer, T.; Bloks, V.W.; Boverhof, R.; Nieuwdorp, M.; et al. Transintestinal Cholesterol Transport Is Active in Mice and Humans and Controls Ezetimibe-Induced Fecal Neutral Sterol Excretion. Cell Metab. 2016, 24, 783-794. [CrossRef]

44. Vrins, C.; van der Velde, A.; van den Oever, K.; Kunne, C.; van Eck, M.; Rensen, P.; Groen, A. Trans Intestinal Cholesterol Efflux Pathway Is Reduced in Apoe Knockout Mice. Atheroscler. Suppl. 2008, 9, 29. [CrossRef]

45. Reeskamp, L.F.; Meessen, E.C.E.; Groen, A.K. Transintestinal cholesterol excretion in humans. Curr. Opin. Lipidol. 2018, 29, 10-17. [CrossRef]

46. Moreau, F.; Blanchard, C.; Perret, C.; Flet, L.; Douane, F.; Frampas, E.; Mirallie, E.; Croyal, M.; Aguesse, A.; Krempf, M.; et al. In vivo evidence for transintestinal cholesterol efflux in patients with complete common bile duct obstruction. J. Clin. Lipidol. 2019, 13, 213-217.e211. [CrossRef]

47. Temel, R.E.; Brown, J.M. A new model of reverse cholesterol transport: EnTICEing strategies to stimulate intestinal cholesterol excretion. Trends Pharmacol. Sci. 2015, 36, 440-451. [CrossRef] [PubMed]

48. Alphonse, P.A.S.; Jones, P.J.H. Revisiting Human Cholesterol Synthesis and Absorption: The Reciprocity Paradigm and its Key Regulators. Lipids 2016, 51, 519-536. [CrossRef]

49. Vaklavas, C.; Chatzizisis, Y.S.; Ziakas, A.; Zamboulis, C.; Giannoglouc, G.D. Molecular basis of statin-associated myopathy. Atherosclerosis 2009, 202, 18-28. [CrossRef]

50. Sato, R. Sterol metabolism and SREBP activation. Arch. Biochem. Biophys. 2010, 501, 177-181. [CrossRef]

51. Hussain, M.M. Intestinal lipid absorption and lipoprotein formation. Curr. Opin. Lipidol. 2014, 25, 200-206. [CrossRef] [PubMed]

52. Jia, L.; Betters, J.L.; Yu, L.Q. Niemann-Pick C1-Like 1 (NPC1L1) Protein in Intestinal and Hepatic Cholesterol Transport. Annu. Rev. Physiol. 2011, 73, 239-259. [CrossRef] [PubMed]

53. Kidambi, S.; Patel, S.B. Cholesterol and non-cholesterol sterol transporters: ABCG5, ABCG8 and NPC1L1: A review. Xenobiotica 2008, 38, 1119-1139. [CrossRef]

54. Chang, T.Y.; Chang, C. Ezetimibe blocks internalization of the NPC1L1/cholesterol complex. Cell Metab. 2008, 7, 469-471. [CrossRef]

55. Garcia-Calvo, M.; Lisnock, J.M.; Bull, H.G.; Hawes, B.E.; Burnett, D.A.; Braun, M.P.; Crona, J.H.; Davis, H.R.; Dean, D.C.; Detmers, P.A.; et al. The target of ezetimibe is Niemann-Pick Cl-Like 1 (NPC1L1). Proc. Natl. Acad. Sci. USA 2005, 102, 8132-8137. [CrossRef] [PubMed]

56. Field, F.J.; Watt, K.; Mathur, S.N. Origins of intestinal ABCA1-mediated HDL-cholesterol. J. Lipid Res. 2008, 49, 2605-2619. [CrossRef]

57. Nguyen, T.M.; Sawyer, J.K.; Kelley, K.L.; Davis, M.A.; Rudel, L.L. Cholesterol esterification by ACAT2 is essential for efficient intestinal cholesterol absorption: Evidence from thoracic lymph duct cannulation. J. Lipid Res. 2012, 53, 95-104. [CrossRef]

58. Vidal, R.; Hernandez-Vallejo, S.; Pauquai, T.; Texier, O.; Rousset, M.; Chambaz, J.; Demignot, S.; Lacorte, J.M. Apple procyanidins decrease cholesterol esterification and lipoprotein secretion in Caco-2/TC7 enterocytes. J. Lipid Res. 2005, 46, 258-268. [CrossRef] 
59. Hui, D.Y.; Labonte, E.D.; Howles, P.N. Development and physiological regulation of intestinal lipid absorption. III. Intestinal transporters and cholesterol absorption. Am. J. Physiol. Gastrointest. Liver Physiol. 2008, 294, G839-G843. [CrossRef]

60. Le May, C.; Berger, J.M.; Lespine, A.; Pillot, B.; Prieur, X.; Letessier, E.; Hussain, M.M.; Collet, X.; Cariou, B.; Costet, P. Transintestinal cholesterol excretion is an active metabolic process modulated by PCSK9 and statin involving ABCB1. Arterioscler. Thromb. Vasc. Biol. 2013, 33, 1484-1493. [CrossRef] [PubMed]

61. Houtkooper, R.H.; Pirinen, E.; Auwerx, J. Sirtuins as regulators of metabolism and healthspan. Nat. Rev. Mol. Cell Biol. 2012, 13, 225-238. [CrossRef] [PubMed]

62. Sygitowicz, G.; Sitkiewicz, D. Sirtuins and their role as physiological modulators of metabolism. Postep. Hig. Med. Dosw. 2020, 74, 489-496. [CrossRef]

63. Ye, X.; Li, M.T.; Hou, T.Y.; Gao, T.; Zhu, W.G.; Yang, Y. Sirtuins in glucose and lipid metabolism. Oncotarget 2017, 8, 1845-1859. [CrossRef]

64. Vachharajani, V.T.; Liu, T.F.; Wang, X.F.; Hoth, J.J.; Yoza, B.K.; McCall, C.E. Sirtuins Link Inflammation and Metabolism. J. Immunol. Res. 2016, 2016. [CrossRef] [PubMed]

65. Deng, Z.H.; Li, Y.S.; Liu, H.F.; Xiao, S.S.; Li, L.J.; Tian, J.; Cheng, C.; Zhang, G.; Zhang, F.J. The role of sirtuin 1 and its activator, resveratrol in osteoarthritis. Biosci. Rep. 2019, 39. [CrossRef] [PubMed]

66. Roggerio, A.; Strunz, C.M.C.; Pacanaro, A.P.; Leal, D.P.; Takada, J.Y.; Avakian, S.D.; Mansur, A.D. Gene Expression of Sirtuin-1 and Endogenous Secretory Receptor for Advanced Glycation End Products in Healthy and Slightly Overweight Subjects after Caloric Restriction and Resveratrol Administration. Nutrients 2018, 10, 937. [CrossRef] 